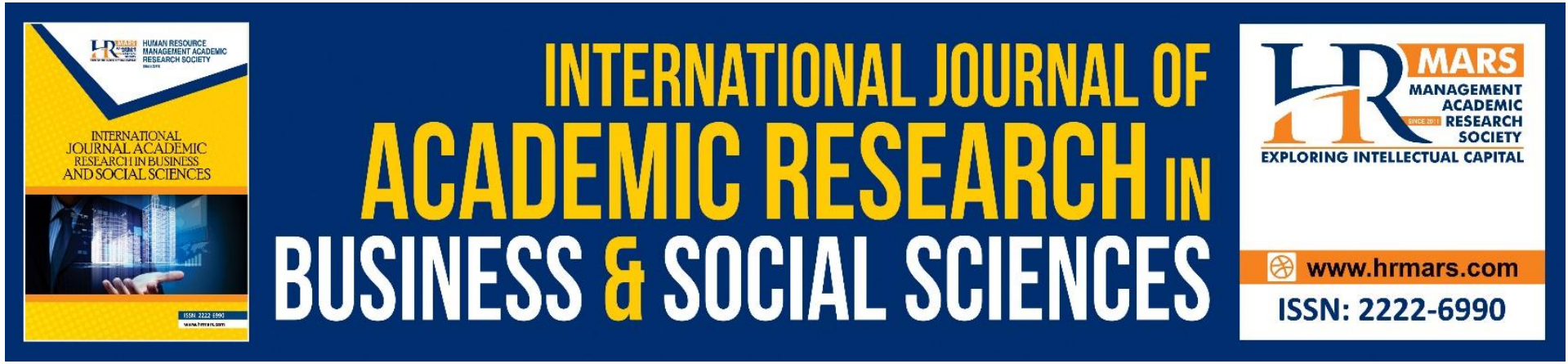

\title{
Examining the Predictors of Willingness to Seek Counselling Services
}

Tan Yee Shin, Noor Syamilah Zakaria, Neerushah Subarimaniam

To Link this Article: http://dx.doi.org/10.6007/IJARBSS/v11-i8/10506 DOI:10.6007/IJARBSS/v11-i8/10506

Received: 24 June 2021, Revised: 26 July 2021, Accepted: 18 August 2021

Published Online: 27 August 2021

In-Text Citation: (Shin et al., 2021)

To Cite this Article: Shin, T. Y., Zakaria, N. S., \& Subarimaniam, N. (2021). Examining the Predictors of Willingness to Seek Counselling Services. International Journal of Academic Research in Business and Social Sciences, 11(8), 1402-1418.

Copyright: (c) 2021 The Author(s)

Published by Human Resource Management Academic Research Society (www.hrmars.com)

This article is published under the Creative Commons Attribution (CC BY 4.0) license. Anyone may reproduce, distribute, translate and create derivative works of this article (for both commercial and non-commercial purposes), subject to full attribution to the original publication and authors. The full terms of this license may be seen at: http://creativecommons.org/licences/by/4.0/legalcode

Vol. 11, No. 8, 2021, Pg. 1402 - 1418

http://hrmars.com/index.php/pages/detail/IJARBSS

JOURNAL HOMEPAGE

Full Terms \& Conditions of access and use can be found at http://hrmars.com/index.php/pages/detail/publication-ethics 


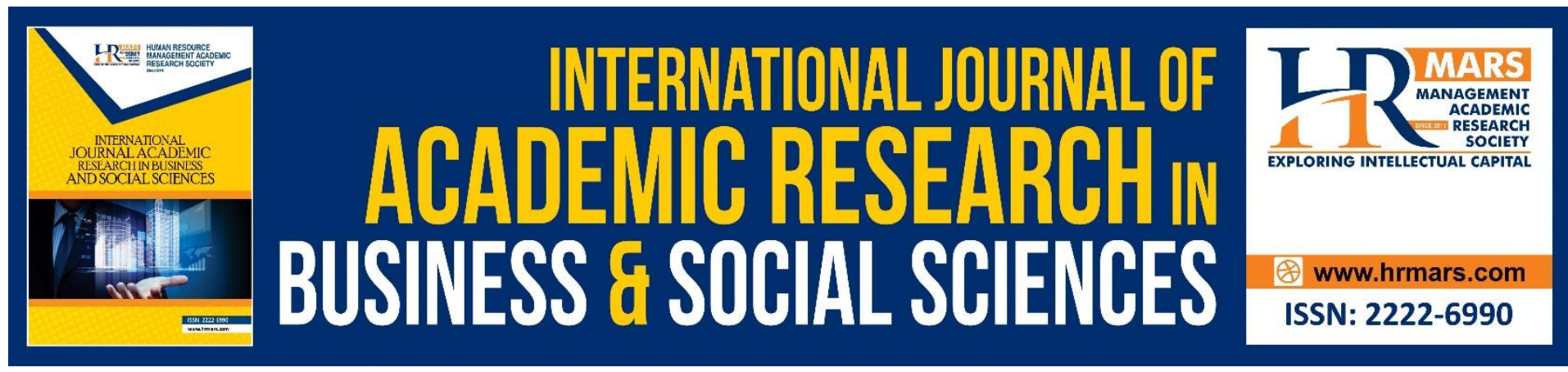

\title{
Examining the Predictors of Willingness to Seek Counselling Services
}

\author{
Tan Yee Shin
}

Department of Counselor Education and Counseling Psychology, Faculty of Educational Studies, Universiti Putra Malaysia, 43400 UPM Serdang, Selangor Darul Ehsan, Malaysia.

\section{Noor Syamilah Zakaria}

Department of Counselor Education and Counseling Psychology, Faculty of Educational Studies, Universiti Putra Malaysia, 43400 UPM Serdang, Selangor Darul Ehsan, Malaysia.

Email: syamilah@upm.edu.my

\section{Neerushah Subarimaniam}

Department of Counselor Education and Counseling Psychology, Faculty of Educational Studies, Universiti Putra Malaysia, 43400 UPM Serdang, Selangor Darul Ehsan, Malaysia.

\begin{abstract}
The state of adolescents' mental well-being has reached an alarming and worrying stage. Adverse life events, patterns of family changes, changes in peer relationships, and accompanied by the emergence of mental health problems are significant factors influencing the development of psychosocial problems among adolescents. Unfortunately, only a small number of adolescents will go for formal sources such as professional counsellors or mental health professionals when they need help. Thus, the main purpose of the present study was to determine the relationships between parent-child connection, social support, and willingness to seek counselling services among secondary school students in a selected district in Selangor, Malaysia. A total of 437 respondents participated in the present study of which were selected through cluster sampling techniques. The findings demonstrated that motherchild regard, mother-child responsibility, father-child responsibility, and family social support were positively correlated with willingness to seek counselling services among secondary school students. This study concluded family social support as a significant predictor of willingness to seek counselling services. Our study would suggest the importance of counsellors to psycho educate the students about the access and functions of counselling services in schools.
\end{abstract}

Keywords: Parent-Adult Child Connection, Social Support, Willingness to Seek Counselling, Secondary School Students, Adolescence.

\section{Introduction}

Adolescence is a period of human development where the schools and parents play roles as critical important socialization agents (Spera, 2005). During this period, adolescents undergo 
the transition to an increased sense of self-exploration and autonomy from a highly dependent and controlled period of childhood (Spera, 2005). The human development is supported by Erik Erikson's theory of psychosocial development. According to Erik Erikson's theory of psychosocial development, there are eight stages of crisis in humans' lives that lead to the formation of individual identities. The eight describes the impact of social experiences across the whole lifespan of individuals (Cherry, 2019). Erikson believed that people will experience conflicts that serve as a turning point in their development (Cherry, 2019). During the fifth stage of psychosocial development, which is from the age of 13 to 21 , adolescents will undergo the stage of identity versus role confusion or identity diffusion. During this stage, adolescents will search for a sense of self and personal identities. Their lives might be stressful specifically in the earlier transitional stage to search for belonging and to be accepted. Moreover, the exploration of personal values, beliefs, and goals will be established too (Cherry, 2019).

In addition, adolescence is a critical developmental period where mental health problems and other related problem behaviours often arise (Heerde \& Hemphill, 2018). This is due to vulnerability and increased sensitivity of adolescents which frequently accompanied with emotional imbalance state such as sadness, helpless, and depressed. (Michael, 2018; Raviv et al., 2000). Furthermore, adolescents also undergo puberty where it is the risky period in terms of subjective well-being and is important for adolescents to reach the efficient psychological resources of help when they are in need (Cakar \& Savi, 2014). However, adverse life events, patterns of family changes, changes of peer relationships, and the emergence of mental health problems are significant factors that influence the development of psychosocial problems among adolescents (Heerde \& Hemphill, 2018). To be specific, parent-child relationship, social support, and willingness to seek help are vital factors that need to be explored as an initiative to help the adolescents.

A parent-child relationship is the socialization between parent and child (Sears, 1951). It is often referred to as the emotional, communicative, and affiliative processes that take place between parents and children. Huffman et al. (2000) claimed that mother-reported chaotic relationships with the child will predict hyperactivity, depression, and delinquency among the children. Moreover, it also predicts aggressiveness, inattentiveness, and self-destructiveness of the children. According to Gonzalez (2017), parenting can be the core elements of child development where good parenting style such as supportive and flexible can lead to welldeveloped children. Gonzalez (2017) also claimed that parenting style can affect the psychosocial well-being of children in advocating them to manage mental health struggles and acceptance in seeking help. In Adlerian Theory, biological, living environment, and family could be critical environments for children pertinently at an early age. Adler believes that the importance of family life and birth order may lead to how a person perceives the environment in the family and this might affect the social interest which is the marker for psychological health (Chao, 2015).

On the other hand, social support is generally defined as a range of interpersonal relationships or connections that have an impact on the individuals' functioning, and generally include support provided by individuals and by social institutions (Baker, 2007). Social support networks were found to be a significant moderator of psychological distress and help-seeking behaviours (Joseph, 2010). Vogel et al. (2007) found that social support from family and friends play an influential role to encourage adolescents to seek help. While Adler refers to the notion of individuals as social beings will lead to their psychological health (Oberst \& Stewart, 2012). The social interest refers to individuals who are able to participate, contribute, 
share, accept, appreciate, and love other people. It also means that the individuals are able to cope and adapt to obstacles and misfortune of lives more socially (Oberst \& Stewart, 2012). World Health Organization (WHO) proposed that help-seeking is an action or activity that an adolescent who perceived herself/himself in needing personal, psychological, affective assistance or health or social services to meet the positive way (Rowe et al., 2014). It can be getting help from formal sources or informal sources. Formal sources include clinic services, counsellors, psychologists, medical staffs, traditional healers, youth programs or religious leaders. Whereas seeking help from informal sources involve peer groups, friends, and family members or other adults in a community.

Help can also be sought from different sources, it is diverse, and vary based on the level of formality. Formal help-seeking includes professionals who have recognized roles and appropriate training in providing help and advice, such as mental health and health professionals, teachers, social workers, and counsellors. Informal help includes getting help from friends, parents or internet sources (Cakar \& Savi, 2014). There are also adolescents who experience depressive mood, high level of tension, and psychosomatic pains which required help and support systems to have a better adjustment, less emotional, and behavioural problems. Therefore, adolescents' ability to seek help and receive assistance and support from the people surrounding becomes crucially important. However, young people are the least likely to seek help (Chen \& Kok, 2015; Maiuolo et al., 2019; Salim, 2010). This is due to the stigma towards mental health and also incorrect assumptions toward counselling services in schools such as counselling is not helpful and constant fear of being judged. Thus, only a handful of students seek help from the school counsellor (Michael, 2018; Raj \& Jamaluddin, 2015).

\section{The Current Study}

In Malaysia, the state of students' mental well-being has reached an alarming and worrying stage. The suicide rate is also increasing among Malaysian youths (Chonghui et al., 2018; Pillay, 2017; Rajaendram, 2019). According to Befriender's Publicity Director (Malaysia), Ardy Ayadali, suicide is the second leading cause of death among youth between the ages of 15 to 29. In addition, the National Survey has revealed that Malaysians aged between 13 to 17 are critically suffering from mental health problems (Chonghui et al., 2018).

Moreover, according to the report prepared based on the Malaysian Education Ministry's Healthy Mind Programme (Program Minda Sihat) 2017, only 5104 out of 284516 students participating received intervention from the school counsellors (Chonghui et al., 2018). From the statistics, we found that only $1.8 \%$ of students seek help from counsellors in the school setting. This shows that only a small number of adolescents seek help from formal sources such as professional counsellors or mental health professionals (Cakar \& Savi, 2014; Maiuolo et al., 2019).

Parents are believed to have involvement in the help-seeking process of adolescents specifically to their mental health problems (Maiuolo et al., 2019). Caregiving relationships such as safe relationships or environment which includes love, care, and attention from the people surrounding will foster internal resilience. In contrast, caregiving relationships from significant individuals such as family members or peers will provide potential external resilience to adolescents (Kuldas et al., 2014). However, school counsellors claimed that students often do not get enough attention from parents and parents expect the school counsellors to help the children (Rajaendram, 2019). 
Therefore, the present study aims to examine factors that may assist adolescents to increase their willingness to seek help. The present study aims to determine the relationships between parent-child connection, social support, and willingness to seek counselling services among the secondary school students in a selected district located in Selangor, Malaysia. In addition, the predictors of willingness to seek counselling services are identified the end of the study.

\section{Methodology}

This study intends to describe the level of parent-child connection, social support, and willingness to seek counselling services among secondary school students in a selected district in Selangor, Malaysia. Furthermore, this study also aims to determine the relationship between parent-child connection and willingness to seek counselling service among the secondary school students. The hypotheses tested are as follows:

Ho1: There is no significant relationship between mother-child connection (regards scale) and willingness to seek counselling service among the secondary school students.

Ho2: There is no significant relationship between mother-child connection (responsibility scale) and willingness to seek counselling service among the secondary school students.

Ho3: There is no significant relationship between father-child connection (regards scale) and willingness to seek counselling service among the secondary school students.

Ho4: There is no significant relationship between father-child connection (responsibility scale) and willingness to seek counselling service among the secondary school students.

Ho5: There is no significant relationship between father-child connection (control scale) and willingness to seek counselling service among the secondary school students.

The current study also aims to determine the relationship between social support and willingness to seek counselling services among secondary school students in a selected district in Selangor, Malaysia. The hypotheses tested are as follows:

Ho6: There is no significant relationship between social support (family factor) and willingness to seek counselling services among the secondary school students.

Ho7: There is no significant relationship between social support (friend factor) and willingness to seek counselling services among the secondary school students.

Ho8: There is no significant relationship between social support and willingness to seek counselling services among the secondary school students.

Finally, this study aims to determine the predictors of willingness to seek counselling services among secondary school students in a selected district in Selangor, Malaysia. For this objective, the hypothesis tested is as follows:

Ho9: There is no likelihood of all the factors to significantly predict the willingness to seek counselling services among the secondary school students.

\section{Sample}

The populations of the present study are adolescents aged 13 to 18 in selected secondary school located in Selangor, Malaysia. The sample was selected from a randomly selected school. According to the data of school enrollment from the Ministry of Education (Malaysia) in 2019, total students enrolled in six government secondary schools and three international 
schools in January 2019 was 9730. The sample size was calculated using Yamane's formula (Yamane, 1967).

$$
n=\frac{N}{1+N(e)^{2}}
$$

where,

$$
\mathrm{n}=\text { the sample size }
$$

$\mathrm{N}=$ the size of population

$\mathrm{e}=$ the error of 5 percentage points.

By using Yamane's formula of sample size with an error of $5 \%$ and with a confidence coefficient of $95 \%$ (Yamane, 1967) the estimated sample size is 370 . The sample selection was performed through a single cluster sampling technique. Three schools were randomly selected from nine schools. Then, five classes were randomly selected from the three schools. The online google form was created to run the data collection process, however, the respond return rate was not in favour. Therefore, a total of 500 questionnaires were distributed to all the students adhering to the sample selection technique. With that, a total of 437 respondents were obtained in the present study and the result was analysed based on the data provided by 437 respondents despite the calculated sample size which is 370 . The data collected was then processed and analysed. Therefore, the final sample size consisted 437 secondary school students.

\section{Instrumentation}

Three instruments that were used to collect data are as follows:

Parent-child Relationship. The parent-child relationship was measured using Parent AdultChild Relationship Questionnaire (PACQ) (Peisah et al., 1999). It is a self-reported instrument to be completed by the child on their relationship with both of the parents and applies to both genders. PACQ consists of two subscales assessing relationship with mother (regard and responsibility). Furthermore, PACQ comprised of 13 items with three subscales assessing the relationship with father (regard, responsibility, and control). It is a Likert-type scale ranging from 3 (very true) to 0 (not true at all). The regard factor is closely similar to attachment or care and filial attitude whereas the responsibility factor reflects the feeling of guilt and burden (Peisah et al., 1999). The Cronbach's alpha values were 0.87 and 0.82 for mother regard factor and responsibility factor respectively. Father factor yielded a Cronbach's alpha of $0.86,0.74$, and 0.87 for the regard factor, responsibility factor, and control factor respectively. The example of items includes "I respect my father's opinion" for relationship with father and "My mother shows her appreciation of me" for the relationship with mother".

Social Support. The social support was measured using Multidimensional Scale of Perceived Social Support (MSPSS) (Zimet et al., 1988). It is a self-reported instrument that is used to assess perceived social support of the respondents. The items are divided into three subscales which reflects the source of social support namely family (fam), friends (fri), and significant others (so). It is a 7-point Likert type scale ranging from 1 (very strongly disagree) to 7 (very strongly agree). The Cronbach's alpha value were $0.91,0.87$, and 0.85 respectively for significant other, family, and friends subscale. The reliability of the total scale was 0.88 (Zimet et al., 1988). The example of items includes "There is a special person who is around when I am in need" represent the support of significant others, "My family really tries to help me" represent the support from family, and "I have friends with whom I can share my joys and sorrow" represent the support from the friends".

Willingness to seek help. Willingness to seek help was measured using the Attitudes Towards Seeking Professional Psychological Help (ATSPPH; Fischer \& Farina, 1995). It is a 4-point Likert 
type scale ranging from 0 (disagree) to 3 (agree). The reliability value of the measure was 0.82 . The example of items includes "If I were experiencing a serious emotional crisis at this point in my life, I would be confident that I could relief in counselling" and "The ideal of talking about problems with a counsellor strikes me as a poor way to get rid of emotional conflicts".

\section{Results and Analysis Objective 1}

The level of parent-child connection, social support, and willingness to seek counselling services among secondary school students were examined. Mean (M), standard deviation (SD), minimum score, and maximum scores of the factors were recorded.

First factor, the parent-child connection represented by five scales which comprised: (a) mother-child connection (regards scale); (b) mother-child connection (responsibility scale); (c) father-child connection (regards scale); and (d) father-child connection (responsibility scale); and (e) father-child connection (control scale).

For (a), among the 437 respondents, only 432 were valid data score and the remaining were missing data. 14 (3.20\%) of them reported to have a low level of regards towards mother, 114 $(26.10 \%)$ recorded moderate level and more than half, 304 (69.60\%) were reported to have a high level of regards towards mother. The minimum score from the current sample was two and the maximum was $15(M=11.590, S D=2.735)$. For $(b)$, there were seven missing data which resulted in 430 valid data. From the 430 obtained data, 26 (5.90\%) reported to have low responsibility level towards mother, 225 (51.50\%) have moderate level, and 179 (41.00\%) have a low level of responsibility towards mother. The minimum obtained by the sample was two and the maximum was $24(\mathrm{M}=15.290, \mathrm{SD}=4.177)$. Then for $(\mathrm{c}), 432$ respondents were used to examine the level of father-child connection (regards scale) due to five missing respondents. The $M$ for this scale was 8.580 and SD was 2.263 with a minimum score of 0 and a maximum score of 12 . From the 432 valid respondents, more than half 247 (56.50\%) of the respondents reported to have a high level of regards scale towards father, 156 (35.70\%) reported to have moderate level, and $29(6.60 \%)$ reported to have a low level of regards. For (d), the fourth parent-child connection resulted in $M=7.300$ and $S D=2.699$. The minimum score obtained was 0 and the maximum score obtained was 12 . From the 433 valid respondents with four missing, $68(15.60 \%)$ of the respondents reported to have a low level of responsibility towards father, 214 (49.00\%) have moderate level, and 151 (34.60\%) reported to have a high level of responsibility towards father. For (e), the final subscale recorded data from 437 respondents with four missing data. 124 (28.40\%) of them reported to have a low level of control by father, $213(48.70 \%)$ reported to have a moderate level, and $96(22.00 \%)$ reported to have a high level of control by father. The $M$ obtained was 7.790 followed by SD which was 3.639. The minimum score obtained was 0 and the maximum score obtained was 15 . For parent-child responsibility scale, there was a moderate sense of responsibility towards both the parents, 225 (51.50\%) of moderate score towards mother and $214(49.00 \%)$ towards father.

The second factor, social support of the respondents was measured using MSPSS. The score for social support of family members reported $M=19.060, S D=5.500$ with a maximum score of 28 and a minimum score of four. 353 respondents (80.80\%) reported having a high level of family support. The same maximum and minimum score was also obtained from the friend support with M 19.180, SD 5.020. There were 362 (82.80\%) of the respondents also reported having a high level of friend support where the $M$ value for social support was 58.050 and SD was 14.300. The respondents' score ranged from 13 to 84 . Among the 432 respondents, 13 
(3.00\%) reported to have a low level of social support in total, $182(41.60 \%)$ moderate, and $237(54.20 \%)$ reported to have a high level of social support.

Finally, for willingness to seek counselling services, the M score was 13.960 , followed by SD 3.548. This indicated that the current sample has a slightly lower level of willingness to seek counselling services. Most of the respondents, 353 (80.80\%) out of 431 respondents reported moderate willingness to seek counselling. Only 11 (2.50\%) reported having a higher intention to seek counselling services whereas $67(15.30 \%)$ of the respondents reported having a low level of willingness to seek counselling services.

Table 1. Categories, Mean, and Standard Deviation of the Factors

\begin{tabular}{|c|c|c|c|c|c|c|}
\hline \multirow[t]{2}{*}{ Variables } & \multirow{2}{*}{$\begin{array}{l}\text { Mean } \\
\mathbf{M}\end{array}$} & \multirow{2}{*}{$\begin{array}{l}\text { Standard } \\
\text { Deviation } \\
\text { SD } \\
\end{array}$} & \multirow[t]{2}{*}{ Min } & \multirow[t]{2}{*}{ Max } & \multirow[t]{2}{*}{$\mathbf{n}$} & \multirow[t]{2}{*}{$\%$} \\
\hline & & & & & & \\
\hline $\begin{array}{l}\text { Mother-child connection } \\
\text { (Regards) }\end{array}$ & 11.590 & 2.735 & 2 & 15 & 432 & \\
\hline Low (0-5) & & & & & 14 & 3.20 \\
\hline Moderate (6-10) & & & & & 114 & 26.10 \\
\hline High (11-15) & & & & & 304 & 69.60 \\
\hline Missing & & & & & 5 & 1.10 \\
\hline $\begin{array}{l}\text { Mother-child connection } \\
\text { (Responsibility) }\end{array}$ & 15.290 & 4.177 & 2 & 24 & 430 & \\
\hline Low $(0-8)$ & & & & & 26 & 5.90 \\
\hline Moderate (9-16) & & & & & 225 & 51.50 \\
\hline High (17-24) & & & & & 179 & 41.0 \\
\hline Missing & & & & & 7 & 1.60 \\
\hline $\begin{array}{l}\text { Father-child connection } \\
\text { (Regards) }\end{array}$ & 8.580 & 2.263 & 0 & 12 & 432 & \\
\hline Low (0-4) & & & & & 29 & 6.60 \\
\hline Moderate (5-8) & & & & & 156 & 35.70 \\
\hline High (9-12) & & & & & 247 & 56.60 \\
\hline Missing & & & & & 5 & 1.10 \\
\hline $\begin{array}{l}\text { Father-child connection } \\
\text { (Responsibility) }\end{array}$ & 7.300 & 2.699 & 0 & 12 & 433 & \\
\hline Low $(0-4)$ & & & & & 68 & 15.60 \\
\hline Moderate (5-8) & & & & & 214 & 14.90 \\
\hline High (9-12) & & & & & 151 & 34.60 \\
\hline Missing & & & & & 4 & 0.90 \\
\hline $\begin{array}{l}\text { Father-Child Connection } \\
\text { (Control) }\end{array}$ & 7.790 & 3.639 & 0 & 15 & 433 & \\
\hline Low (0-5) & & & & & 124 & 28.40 \\
\hline Moderate (6-10) & & & & & 213 & 48.70 \\
\hline High (11-15) & & & & & 96 & 22.00 \\
\hline
\end{tabular}




\begin{tabular}{|c|c|c|c|c|c|c|}
\hline Missing & & & & & 4 & 0.90 \\
\hline $\begin{array}{l}\text { Social support } \\
\text { (Family) }\end{array}$ & 19.060 & 5.500 & 4 & 28 & 432 & \\
\hline Low (1-14) & & & & & 83 & 19.00 \\
\hline High (15-28) & & & & & 353 & 80.80 \\
\hline Missing & & & & & 1 & 0.20 \\
\hline $\begin{array}{l}\text { Social support } \\
\text { (Friend) }\end{array}$ & 19.180 & 5.020 & 4 & 28 & 432 & \\
\hline Low (1-14) & & & & & 72 & 16.50 \\
\hline High (15-28) & & & & & 362 & 82.80 \\
\hline Missing & & & & & 3 & 0.70 \\
\hline Social support & 58.050 & 14.300 & 13 & 84 & 432 & \\
\hline Low (12-28) & & & & & 13 & 3.00 \\
\hline Moderate (29-56) & & & & & 182 & 41.60 \\
\hline High (57-84) & & & & & 237 & 54.20 \\
\hline Missing & & & & & 5 & 1.10 \\
\hline $\begin{array}{l}\text { Willingness to seek } \\
\text { counselling services }\end{array}$ & 13.960 & 3.548 & 2 & 28 & 431 & \\
\hline Low (0-10) & & & & & 67 & 15.3 \\
\hline Moderate (11-20) & & & & & 353 & 80.8 \\
\hline High (21-30) & & & & & 11 & 2.50 \\
\hline Missing & & & & & 6 & 1.40 \\
\hline
\end{tabular}

\section{Objective 2}

The bivariate relationships between factors as shown in Table 2 were analysed using Pearson's Product-Moment correlation analysis. This analysis was a prerequisite for determining the predictors of willingness to seek counselling services through Multiple Regression Analysis.

First, findings indicated a significant low positive correlation between mother-child relationship (regards scale) and willingness to seek counselling services among the respondents $(r=0.183, p<0.01)$. This result indicated that the higher the level of regards towards mother, the higher the level of willingness to seek counselling services. Therefore, Ho1 there is no significant relationship between mother-child connection (regards scale) and willingness to seek counselling services among secondary school students is rejected.

Second, there is a significant low positive correlation of mother-child responsibility scale and willingness to seek counselling services $(r=0.127, p<0.01)$. This showed that the higher the responsibility towards mother of the respondents, the higher the willingness to seek counselling services. Therefore, $\mathrm{Ho} 2$ there is no significant relationship between mother-child connection (responsibility scale) and willingness to seek counselling services among secondary school students is rejected.

Third, the findings showed that there is no significant relationship between father-child relationship (regard scale) $(r=-0.012, p=0.806)$. Therefore, Ho3 there is no significant 
relationship between father-child connection (regard scale) and willingness to seek counselling services among secondary school students is accepted.

Fourth, the findings indicated that there is a positive correlation of father-child connection (responsibility scale) towards willingness to seek counselling service $(r=0.116, p<0.05)$. This showed that the higher the level of responsibility towards father, the higher the level of willingness to seek counselling service. Therefore, hypothesis Ho4 there is no significant relationship between father-child connection (regards scale) and willingness to seek counselling services among secondary school students is rejected.

Fifth, the findings showed that there is no significant relationship between father-child relationship (control scale) with willingness to seek counselling services $(r=0.004, p=0.928)$. Therefore, Ho5 there is no significant relationship between father-child connection (control factor) and willingness to seek counselling services among secondary school students is accepted.

Sixth, there is a significant low positive relationship between family support and willingness to seek counselling services $(r=0.194, p<0.01)$. Therefore, Ho6 there is no significant relationship between social support (family) and willingness to seek counselling services among secondary school students is rejected. This show that the higher the family support, the higher the willingness to seek counselling services.

Seventh, there is no significant relationship between friend support and willingness to seek counselling services $(r=-0.024, p=0.618)$. Therefore, Ho7 there is no significant relationship between social support (friend) and willingness to seek counselling services among secondary school students is accepted.

Finally, the findings revealed that there is no significant relationship between social support and willingness to seek counselling services $(r=-0.82, p=0.92)$. Therefore, Ho8 there is no significant relationship between social support and willingness to seek counselling services among secondary school students is accepted. 
Table 2. Pearson's Product -Moment Correlation Coefficients Matrix between the Factors

\begin{tabular}{|c|c|c|c|c|c|c|c|c|}
\hline \multirow{2}{*}{\multicolumn{9}{|c|}{$\begin{array}{l}\text { Factors } \\
\text { Mother-child } \\
\text { connection } \\
\text { (Regard) }\end{array}$}} \\
\hline & & & & & & & & \\
\hline $\begin{array}{l}\text { Mother-child } \\
\text { connection } \\
\text { (Responsibility) }\end{array}$ & $\begin{array}{l}0.472^{*} \\
*\end{array}$ & & & & & & & \\
\hline $\begin{array}{l}\text { Father-child } \\
\text { connection } \\
\text { (Regard) }\end{array}$ & $\begin{array}{l}0.423^{*} \\
*\end{array}$ & $\begin{array}{l}0.261^{*} \\
*\end{array}$ & & & & & & \\
\hline $\begin{array}{l}\text { Father-child } \\
\text { connection } \\
\text { (Responsibility) }\end{array}$ & $\begin{array}{l}0.368 * \\
*\end{array}$ & $\begin{array}{l}0.487^{*} \\
*\end{array}$ & $\begin{array}{l}0.589 * \\
*\end{array}$ & & & & & \\
\hline $\begin{array}{l}\text { Father-child } \\
\text { connection } \\
\text { (Control) } \\
\end{array}$ & -0.056 & 0.360 & 0.063 & $\begin{array}{l}0.283 * \\
*\end{array}$ & & & & \\
\hline $\begin{array}{l}\text { Social support } \\
\text { (Family) }\end{array}$ & $\begin{array}{l}0.499 * \\
*\end{array}$ & $\begin{array}{l}0.209 * \\
*\end{array}$ & $\begin{array}{l}0.331^{*} \\
*\end{array}$ & $\begin{array}{l}0.249 * \\
* \\
\end{array}$ & $\begin{array}{l}- \\
0.208 * \\
*\end{array}$ & & & \\
\hline $\begin{array}{l}\text { Social support } \\
\text { (Friends) }\end{array}$ & $\begin{array}{l}0.200 * \\
*\end{array}$ & $\begin{array}{l}0.157^{*} \\
* \\
\end{array}$ & $\begin{array}{l}0.204^{*} \\
*\end{array}$ & $\begin{array}{l}0.138^{*} \\
*\end{array}$ & $0.095^{*}$ & $\begin{array}{l}0.401 * \\
*\end{array}$ & & \\
\hline $\begin{array}{l}\text { Social support } \\
\text { (Total) }\end{array}$ & $\begin{array}{l}0 . .395 * \\
*\end{array}$ & $\begin{array}{l}0.233^{*} \\
*\end{array}$ & $\begin{array}{l}0.318^{*} \\
*\end{array}$ & $\begin{array}{l}0.245^{*} \\
*\end{array}$ & $\begin{array}{l}- \\
0.165^{*} \\
*\end{array}$ & $\begin{array}{l}0.783 * \\
*\end{array}$ & $\begin{array}{l}0.794 * \\
*\end{array}$ & \\
\hline $\begin{array}{l}\text { Willingness to } \\
\text { seek counselling } \\
\text { services } \\
\text { (Overall) }\end{array}$ & $\begin{array}{l}0.183^{*} \\
*\end{array}$ & $\begin{array}{l}0.127^{*} \\
*\end{array}$ & -0.012 & $0.116^{*}$ & 0.004 & $\begin{array}{l}0.194^{*} \\
*\end{array}$ & -0.024 & 0.082 \\
\hline
\end{tabular}

*Correlation is significant at the 0.05 level ( 2 - tailed)

**Correlation is significant at the 0.01 level $(2$ - tailed)

\section{Objective 3}

Multivariate analysis was carried out to determine the significant predictors of willingness to seek counselling services among secondary school students. Multiple linear regression was employed to predict the factors of willingness to seek counselling services.

Table 3 displayed the results from multiple linear regression analysis that was conducted to predict willingness to seek counselling services among secondary school students using mother-child connection (regard scale), mother-child connection (responsibility scale), father-child connection (responsibility scale), and social support (family scale) which have significant relationship with willingness to seek counselling services. The willingness to seek counselling services is significantly different for four factors, $F(4,413)=3.474, p<0.05$. With the $p$ value less than 0.05 , it can be concluded that Ho9 there is no likelihood of all factors significantly predict the willingness to seek counselling services among secondary school students is rejected. The predictor that predicted the willingness to seek counselling services is social support (family scale) with $ß$ of 0.141 . The adjusted $R^{2}$ value was 0.042 . 
Table 3. Predictors of Willingness to Seek Counselling Services among Secondary School Students $(\mathrm{N}=437)$

\begin{tabular}{llll}
\hline Variables & B & SEB & B \\
\hline $\begin{array}{l}\text { Mother-child } \\
\text { connection } \\
\text { (Responsibility) }\end{array}$ & 0.123 & 0.080 & 0.095 \\
\hline $\begin{array}{l}\text { Mother-child } \\
\text { connection (Regards) }\end{array}$ & 0.019 & 0.051 & 0.022 \\
\hline $\begin{array}{l}\text { Father-child } \\
\text { connection } \\
\text { (Responsibility) }\end{array}$ & 0.042 & 0.073 & 0.032 \\
\hline $\begin{array}{l}\text { Social support } \\
\text { (Family) }\end{array}$ & 0.091 & 0.036 & $0.141^{*}$ \\
\hline $\mathrm{R}^{2}=0.051$, Adjusted $\mathrm{R}^{2}=0.042, \mathrm{~F}=3.474, \mathrm{p}<0.05$ &
\end{tabular}

\section{Discussion}

\section{Objective 1}

The level of willingness to seek counselling services among the secondary school students was found to be relatively low. As we can see from the results of findings, most of the students reported having a moderate level of willingness to seek counselling services $(80.80 \%)$ and only $2.50 \%$ of the students reported having a high level of willingness to seek counselling services. This is in line with most of the research that the intention of seeking for professional or psychological help among students is still in the low level (Chen \& Kok, 2015; Chonghui et al., 2018; Salim, 2010). These findings provided a statistic for the counsellors in schools that the number of students who are willing to seek counselling services is relatively low. Therefore, efforts are needed to educate students about counselling and encourage them to seek counselling services when they are in need.

We can also infer that secondary school students possibly are not aware of the counselling services or have a stigma towards counselling services provided in the schools which resulted in a low and moderate level of willingness to seek counselling services. Furthermore, there might be still the misconception of students towards counselling services that counselling services are for those who are having behavioural or disciplinary problems (Chen \& Kok, 2015). In addition, the low level of willingness to seek counselling services might be also explained by the negative perceptions on the counselling services. The students may think that seeking help behaviours bring shame to self and family and have a stigma that counselling is always associated with mental health problems or is a sign of weakness (Vogel et al., 2010). Furthermore, by comparing the score obtained for the mother and father, we found that the respondents have higher regards to mother compared to the father. $304(69.60 \%)$ of respondents reported having a better sense of regards towards mother than 247 (56.50\%) of regards towards father. Also, the responsibility scale towards mother is higher compared to the father. Therefore, we can infer that the secondary school students are having more attachment and filial relationship towards mothers compared to their fathers.

For the overall social support level, more than half of the secondary school students reported having a high social support level. 237 (54.20\%) of the respondents are having a high level of social support. Comparing friend support and family support, it is found that secondary school students reported having higher friend support compared to family support. This finding 
shows that secondary school students would find friend as more supportive compared to their family. However, friends and family members remain accessible as the support systems of the respondents.

\section{Objective 2}

The findings confirmed that there is relationship between the parent child-connection and willingness to seek counselling services among the secondary school students specifically the mother-child connection on regard and responsibility scale. Results also showed significant relationship between the father-child connection on responsibility scale and willingness to seek counselling. This indicated that parents pertinently mothers play important role on students' willingness to seek counselling services. This is supported by the research done by Ayse and Ayhan (2015) which showed that the secure attachment style cause individuals to have more positive attitudes in help seeking. This is supported by the past researchers which claimed that parents play a role in the help seeking process (Gonzalez, 2017; Holt, 2014; Maiuolo, 2019; Wahlin \& Deane, 2012).

Results also showed stronger correlation of mother-child connection compared to fatherchild connection. Therefore, this can be explained that the mothers influence more on the willingness to seek counselling services among secondary school students. This may be due to the nature of mothers where they were found to be having strong attachment and more time with their children. In addition, women are found to be more emotionally expressive and have more caring responsibilities for their children. They will always advice their children and these behaviours are different from fathers who are more socially connected from the outside world generally. Therefore, the amount of time spent by fathers with their children might be more less compared to mother. Therefore, this inferred that the mother-child connection contributes to willingness to seek counselling services.

Furthermore, higher regard and responsibility or in other term attachment and filial relationship with mother may contribute to having a higher social interest and cause individuals to be more psychologically well. Therefore, the present study also explained Alder theory where the higher contribution (regard and responsibility) of a secondary student towards his or her mother, the higher the student would be more psychologically well and able to cope with obstacles in more socially adaptive way by seeking for counselling help (Oberst \& Stewart, 2012).

\section{Objective 3}

The findings revealed that there is a significant relationship between family support and willingness to seek counselling services. Result showed that there is a low positive correlation between family support and the willingness to seek counselling services. This means that the higher the family support, the higher the willingness to seek counselling services. This finding is in line with the prior research focused on social support and willingness to seek counselling services. From here, we can explain that family support plays an important role in the secondary school students' help seeking behaviours (Harris \& Mollock, 2000; Joseph, 2010; Voget et al., 2007). This can be further explained that family members including siblings might be great support system of the respondents.

However, the result showed no significant relationship between friend social support and willingness to seek counselling services. There is also no relationship between overall social support and willingness to seek counselling services. This is also consistent with the research 
where family social support was found to be significantly the help seeking behaviours (Maiuolo et al., 2019).

\section{Objective 4}

Among the variables been tested, there are a total of four variables that are significantly associated with the willingness to seek counselling services which are mother-child connection (regard and responsibility scale), father-child connection (responsibility scale), and social support (family scale). We found that family support is the predictor of willingness to seek counselling services. This is in line with the past research which concludes that family is always the biggest influence of the willingness to seek help (Hagen et al., 2016; Maiuolo et al., 2019; Vogel \& Wei, 2005). This showed that in Malaysia, family members still play an important role in secondary school students' lives.

\section{Conclusion}

The present study showed that parent-child connection specifically mother-child connection and family social support are significantly related to willingness to seek counselling services among secondary school students. In addition, multiple linear regressions also showed that family support significantly contributed to the willingness to seek counselling services. In accordance with willingness to seek counselling, social support pertinently the family support showed a significant relationship and act as the predictors of the willingness to seek counselling services among secondary school students. This indicated that individuals' behaviours are influenced by the microsystem which included family, friends, and environment through the direct context. Adler proposed that the social interest of a person will bring to the psychological well-being of a person. Parent-child connection measures the responsibility and regards of students towards both parents. According to Adler, if a person has a higher contribution to the social surrounding, they are found to be more psychological well or responsible to their emotions and behaviours. Thus, this indicates that the individuals are more responsible on their own well-being and if they have found to have a better social interest, then they are more likely to contribute, give, and accept the love of both their parents.

The school counsellors can try to educate or carry out programs for students to understand more about the counselling services provided in the school and instil awareness that seeking help is not harmful. The school counsellors also may try to have counselling activities involving both parents' and students' interactions to have a better understanding of the dynamic of the students, eventually, help them to overcome mental health problems.

Theoretically, this research would contribute to the existing body of knowledge on predictors of willingness to seek counselling services. The researcher found that family support contributed to individuals' willingness to seek counselling services. This finding is in line with Adler's Theory which highlighted the value of parent-child specifically mother-child relationship and how it would contribute to family well-being. Practically, this research would create community awareness on the importance of relationship among family members which eventually would improve school students' lives. Connecting with family members and fostering family functioning reflect collectivist culture of Malaysia.

Thus, it is recommended that future research can include more variables related to parentchild interaction, mental health awareness, and suicidal ideation with the willingness to seeking counselling services. The quantitative design method was applied in the present study where data were collected from the questionnaire distributed in a closed-ended format. 
Therefore, the qualitative method can be considered in future research to obtain more information on how the secondary school students perceived their relationship with parents and to what extent this affected their lives.

\section{References}

Ayse, I., \& Ayhan, D. (2015). The effect of attachment styles on attitude towards help seeking. Journal of the Faculty of Education, 11(3), 1063-1074. https://doi.org/10.17860/efd.87991

Baker, G. (2007). Adolescents, social support, and help-seeking behaviour: An international literature review and programme consultation with recommendations for action. World Health Organization. https://apps.who.int/iris/handle/10665/43778

Cakar, F. S., \& Savi, S. (2014). An exploratory study of adolescent's help-seeking sources. Journal of Social and Behavioural Sciences, 159, 610-614.

Chao, R. C. L. (2015). Counselling Psychology: An Integrated Positive Psychological Approach. John Wiley \& Sons Ltd. https://www.wiley.com/enus/Counseling+Psychology\%3A+An+Integrated+Positi

ve+Psychological+Approach-p-9781118468128

Chen, K. S., \& Kok, J. K. (2015). Barriers to seeking school counselling: Malaysia Chinese school students' perspective. Journal of Psychologists and Counsellors in Schools, 27(2), 222238. https://doi. org/10.1017/jgc.2015.21

Cherry, K. (2019, April 04). Erik Erikson's stages of psychosocial development. Very Well Mind. https://www.very wellmind.com/erik-eriksons-stages-of-psychosocial-development2795740.

Chonghui, L., Menon, S., \& Rajaendram, R. (2018, October 12). Too many teens suffering from stress. The Star. https://www.thestar.com.my/news/nation/2018/10/12/too-manyteens-suffering-from-stress-examorieNted-culture-not-only-affecting-students-butteachers-a/

Fischer, E. H., \& Farina, A. (1995). Attitudes towards seeking professional psychological help: A shortened form and considerations for research. Journal of College Student Development, 36(4), 368-373. https://psycnet.apa.org/record/1996-10056-001

Gonzalez, A. (2017). The effect of parenting styles on academic self-efficacy, resilience, and help seeking [Master dissertation, Central Washington University]. https://digitalcommons.cwu.edu/etd/594

Hagen, J. A., Dugo, A. T., Anhorn, L., Holsten, B., Werner, V., \& Krebs, S. (2016). Exploring individual differences in online and face-to-face help-seeking intentions in case of impending mental health problems: The role of adult attachment, perceived social support, psychological distress and self-stigma. Journal of Health and Social Sciences, 1(3), 223-240. https://journalhss.com/wp-content/uploads/JHHS 13_223-240.pdf

Harris, T. L., \& Molock, S. D. (2000). Cultural orientation, family cohesion and family support in suicide ideation and depression among African American college students. Suicide and Life-Threatening Behaviour, 30(4), 341-353.

https://pubmed.ncbi.nlm.nih.gov/11210059/

Heerde, J. A., \& Hemphill, S. A. (2018) Examination of associations between informal helpseeking behaviour, social support, and adolescent psychosocial outcomes: A metaanalysis. Developmental Review, 47, 44-62.

https://psycnet.apa.org/doi/10.1016/j.dr.2017.10.001 
Holt, L. J. (2014). Help seeking and social competence mediate the parental attachmentcollege student adjustment relation. Personal Relationships, 21(4), 640-654. https://psycnet.apa.org/doi/10.1111/pere.1 2055

Huffman, L. C., Mehlinger, S. L., \& Kerivan, A. S. (2000). Risk factors for academic and behavioural problems at the beginning of school [Doctoral dissertation, Stanford University. https://files.eric.ed.gov/fulltext/ED476378.pdf

Joseph, J. (2010). Willingness to seek professional psychological help among Canadians of African descent: A culturally based help-seeking model [Doctoral dissertation, University of Windsor].

https://scholar.uwindsor.ca/etd/487?utm_source=scholar.uwindsor.ca\%2Fetd\%2F487 \&utm_medium=PDF\&utm_campaign=PDFCoverPages

Kuldas, S., Shahabuddin, H., \& Ismail, H. N. (2014). Malaysian adolescent students' needs for enhancing thinking skills, counteracting risk factors and demonstrating academic resilience. International Journal of Adolescence and Youth, 20(1), 32-47. https://psycnet.apa.org/doi/10.1080/02673843.2014.973890

Maiuolo, M., Deane, F. P., \& Ciarrochi, J. (2019). Parental authoritativeness, social support, and help-seeking for mental help problems in adolescents. Journal of Youth and Adolescence, 48(6), 1056-1067.https://doi.org/10.1007/s10964-019-00994-4

Micheal, M. (2018). Counsellors a must for all schools, says expert. FMT News. https://www.free.freemalaysiatoday.com/category/nation/2018/02/01/counsellors-amust-for-all-schools-saysexexpert/

Oberst, U. E., \& Stewart, A. E. (2012). Adlerian Psychotherapy: An Advanced Approach to Individual Psychology. Brunner-Routledge.

Peisah, C., Brodaty, H., Luscombe, G., Kruk, J., \& Anstey, K. (1999). The parent adult-child relationship questionnaire (PACQ): The assessment of the relationship of adult children to their parents. Aging \& Mental Health, 3(1), 28-38. https://doi.org/10.1080/13607869956415

Pillay, S. (2017). Suicide on the rise among Malaysian youth. New Straits Times. https://www.nst.com.my/news/exclusive/2017/05/243354/suicide-rise-amongmalaysian-youth

Raviv, A., Sills, R., Raviv, A., \& Wilansky, P. (2000). Adolescents' help-seeking behaviour: The difference between self and other referral. Journal of Adolescence, 23, 721-740. https://doi.org/10.1006/jado.2000.0355

Raj, R., \& Jamaluddin, N. H. (2015, Nov 29). Ministry to define role of school counsellors. Malay Mail. https://www.malaymail.com/news/malaysia/2015/11/29/ministry-todefine-role-ofschoolcounsellors/1 013775

Rajaendram, R. (2019, Aug 04). More counsellors needed at schools. The Star. https://www.thestar.com .my/news/education/2019/08/04/more-counsellorsneeded-at-schools

Rowe, S. L., French, R. S., Henderson, C., Ougrin, D., Slade, M., \& Moran, P. (2014). Helpseeking behaviour and adolescent self-harm: A systematic review. Australian \& New Zealand Journal of Psychiatry, 48(12), 1083-1095. https://doi.org/10.1177/0004867414555718

Salim, S. (2010) Psychological help seeking attitudes among Malaysian College and university students. Procedia Social and Behavioural Sciences, 5, 426-430. https://doi.org/10.1016/j.sbspro.2010.07.117 
Sears, R. R. (1951). A theoretical framework for personality and social behaviour. American Psychologist, 6, 476-483. https://doi.org/10.1037/H0063671

Spera, C. (2005). A review of the relationship among parenting practices, parent styles, and adolescent school achievement. Educational Psychology Review, 17(2). 125-145. https://doi.org/10.1007/s10648-005-3950-1

Vogel, D. L., \& Wei, M. (2005). Adult attachment and help-seeking intent: The mediating roles of psychological distress and perceived social support. Journal of Counselling Psychology, 52(3), 347-357. https://psycnet.apa.org/doi/10.1037/0022-0167.52.3.347

Vogel, D. L., Wester, S. R., \& Larson, L. M. (2007). Avoidance of counselling: Psychological factors that inhibit seeking help. Journal of Counselling and Development, 85, 410-422. https://psycnet.apa.org/doi/10.1002/j.1556-6678.2007.tb00609.x

Wahlin, T., \& Deane, F. P. (2012). Discrepancies between parent-and adolescent-perceived problem severity and influences on help-seeking from mental health services. Australian and New Zealand Journal of Psychiatry, 46(6), 553-560. https://doi.org/10.1177\%2F0004867412441929

Yamane, T. (1967). Statistics: An Introductory Analysis. Harper and Row. https://www.gbv.de/dms/zbw/252560191.pdf

Zimet, G. D., Dahlem, N. W., Zimet, S. G., \& Farley, G. K. (1988). The Multidimensional Scale of Perceived Social Support. Journal of Personality Assessment, 52, 30-41. https://psycnet.apa.org/doi/10.1207/s15327752jpa5201_2 